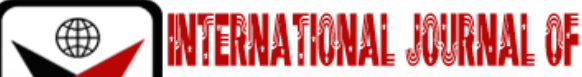 \\ בmRक
}

ISSN 2278-0211 (Online)

\section{Heavy Metal Contamination of Borehole Water of Selected Settlements in the Coastal Area of Ondo-State, Nigeria}

Dr. O. Terebo
Senior Lecturer, Department of Environmental Health,
College of Health Technology, Akure, Ondo State, Nigeria
Dr. A.A. Soyingbe
Senior Lecturer, Department of Environmental Health Sciences,
Ogun State College of Health Technology, Ilese, Ogun State, Nigeria
Dr. O. Olayinka
Associate Professor, Department of Environmental Management \& Toxicology,
Federal University of Agriculture, Abeokuta, Nigeria
O. Bamgbose.
Professor, Department of Environmental Management \& Toxicology,
Federal University of Agriculture, Abeokuta, Nigeria
W. O. Abdul
Professor, Department of Aquaculture \& Fisheries Management,
Federal University of Agriculture, Abeokuta, Nigeria

\begin{abstract}
:
Heavy metal contamination of the borehole water in the coastal area of Ondo state was assessed by monitoring 264 borehole water samples covering 33 locations divided into four districts (identified as I, II, III \& IV) between 2017 and 2019. The metal concentrations of Copper, Lead, Cadmium, Zinc, Chromium, Nickel, Iron, Manganese, Cobalt and Vanadiumwere determined using standard methods. The metal concentrations were within WHO limits except for $\mathrm{Pb}(0.21 \mathrm{mg} / \mathrm{L})$ in District III. Seasonal variation in mean concentration of heavy metals were; Zinc $(0.03 \pm 0.01,0.03 \pm 0.04 \mathrm{mg} / \mathrm{L})$, Chromium $(0.01 \pm 0.00,0.01 \pm 0.01 \mathrm{mg} / \mathrm{L})$, Iron $(0.58 \pm 0.07,0.12 \pm 0.15 \mathrm{mg} / \mathrm{L})$, Cadmium $(0.003 \pm 0.00,0.01 \pm 0.01)$, Nickel $(0.003 \pm 0.00,0.004 \pm 0.01 \mathrm{mg} / \mathrm{L})$, Manganese $(0.02 \pm 0.01,0.03 \pm 0.01 \mathrm{mg} / \mathrm{L})$, Copper $(0.02 \pm 0.00,0.03 \pm 0.01 \mathrm{mg} / \mathrm{L})$, Lead $(0.01 \pm 0.00,0.003 \pm 0.01 \mathrm{mg} / \mathrm{L})$, Cobalt $(0.004 \pm 0.00,0.002 \pm 0.01 \mathrm{mg} / \mathrm{L})$ and Vanadium $(0.003 \pm 0.00,0.03 \pm 0.01 \mathrm{mg} / \mathrm{L})$ for rainy and dry seasons respectively. There was significant difference $(p<0.05)$ for $\mathrm{Cr}, \mathrm{Fe}, \mathrm{Cd}, \mathrm{Cu}$ and $\mathrm{Co}$, with no significant difference $\mathrm{p}<0.05$ ) observed for $\mathrm{Zn}, \mathrm{Ni}, \mathrm{Mn}$ and $\mathrm{V}$ between seasons. The results obtained from this study suggest no significant risk to this population given the toxicity of these metals with exception of lead in district III.
\end{abstract}

Keywords: AAS, borehole water, heavy metals, maximum contamination level and WHO

\section{Introduction}

In Nigeria Niger Delta Region, and indeed Nigeria, the problem of water resources is the availability of goodquality (potable) water because of environmental pollution and degradation (Nduka and Orisakwe, 2010); beside this, valuable man-hours and resources are spent traveling long distances fetching water of doubtful quality.

The southern part of Ondo State (Southwestern, Nigeria) is characterised by numerous surface water bodies. Groundwater is not common in the area, since the aquifer is very deep and will require huge investment for the more than 400 communities. More than $70 \%$ of the area is underlain by various non aquiferous rocks thereby making it a herculean task to sink water boreholes. These factors thereby make the inhabitants to harness the surface water more for their drinking and domestic needs including agricultural activities.

Previous studies have shown that water resources in Nigeria are easily contaminated from anthropogenic activities (Efeet.al., 2005). The uncontrolled discharge of untreated effluents into natural receptors by industries in Nigeria has been reported (Atubi, 2011). Since a strong relationship exist between human activities and pollution of the environment, the recognition of this connection and the need to protect human health, recreation, and fisheries production led to the early development of water-quality regulations and monitoring methods (Corvalanet.al., 2005). The rapid urbanization and industrialization of the Niger Delta Region of Nigeria occasioned by huge crude oil and gas reserves has its toll on the environment (Offiong and Cocodia, 2011). The US Department of Energy estimates that since 1960, there has been more than 4,000 oil spills, discharging several million barrels of crude oil into the ponds, ditches, creeks, beaches, 
streams, and rivers of the Niger Delta (Nduka and Orisakwe, 2011).The Niger Delta is characterized by vociferous public outcry, youth restiveness, and militancy because of huge environmental degradation and acclaimed government marginalization and neglect. Whereas the facts of environmental devastation may be self-evident so to say, articulate and comprehensive scientific data which demonstrate these issues are scant.

\section{Materials and Methods}

\subsection{Description of the Study Area}

The study areas comprised mainly selected communities in Ilaje and Ese-odo Local Government Areas of Ondo state, Nigeria. Ondo State comprises of eighteen (18) Local Government Areas. Ilaje Local Government consists of over four hundred settlements covering an area of 3,000 square kilometres (Adelekeet.al., 2015). This area constitutes one of the major oils producing areas in the state and part of the Niger Delta region of Nigeria. The estimated population of Ilaje LGA is about 254,235 according to Population Census of 2006. However, Ese-odo LGA has a landed area of $762 \mathrm{~km}^{2}$ with a population of 154,978 (NPC, 2006). It lies between longitudes 2'24 to 3'24 and latitudes 6'22 to 6'42. The mean annual total rainfall is $>2000 \mathrm{~mm}$ with a mean monthly temperature of $28-29^{\circ} \mathrm{C}$ (Adelekeet.al., 2015).

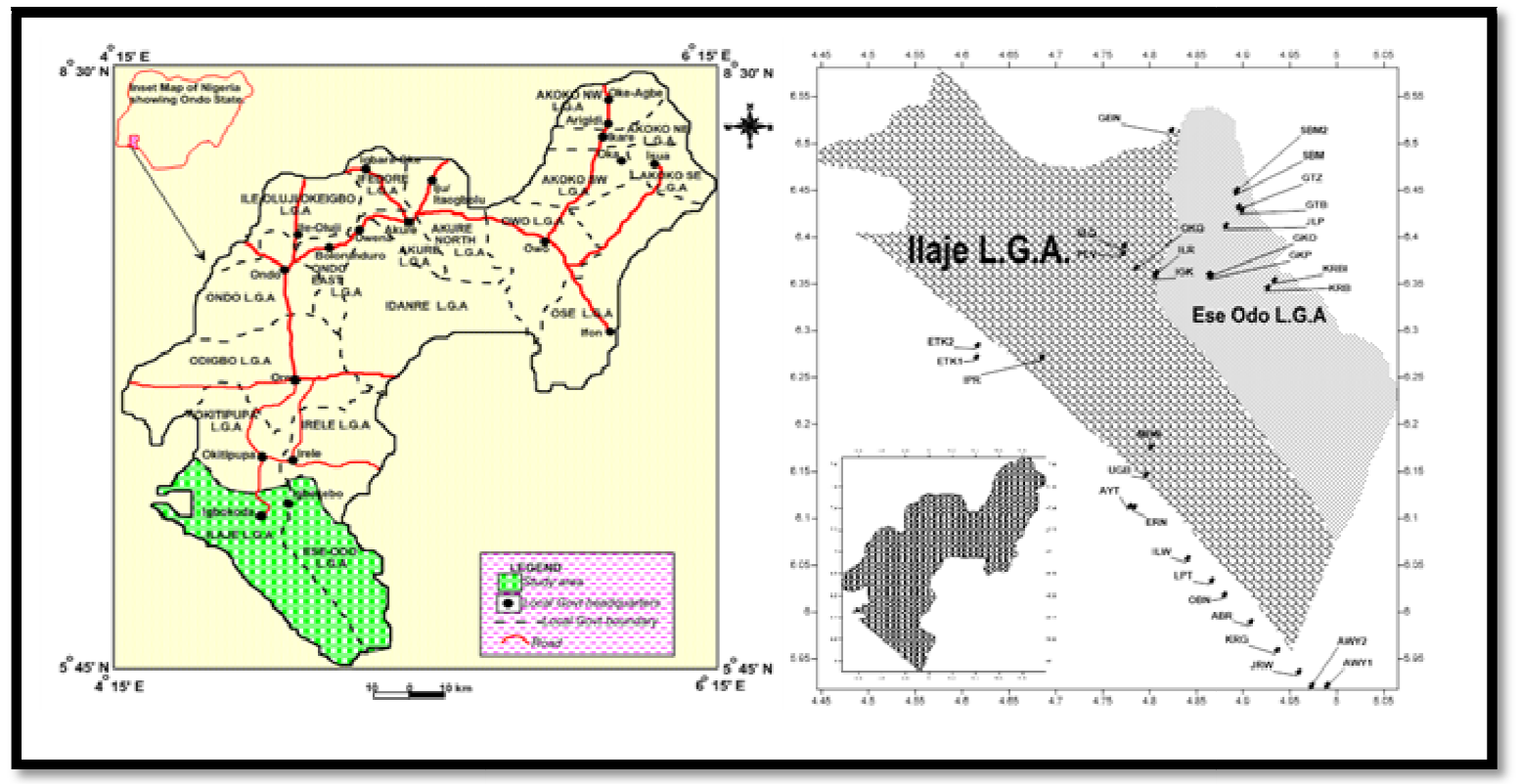

Figure 1: - Map of Study Area

\begin{tabular}{|c|c|c|c|}
\hline $\begin{array}{l}\text { Alagbaka-Akure Water work } \\
\text { Owena-Ondo Water work } \\
\text { Igbaraoke-Ilesha Water works }\end{array}$ & $\begin{array}{l}\text { Awoyo (AWY 1) } \\
\text { Ayetoro (AYT) } \\
\text { Ikarigho (KRG) } \\
\text { llowo (ILW) } \\
\text { Tlepete (LPT) } \\
\text { Jirinwo (JRW) } \\
\text { Erunna (ERN) } \\
\text { Obe-Rewoye (ABR) } \\
\text { Obe- Rebininu (AWY 2) } \\
\text { Obe- Nla (OBN) } \\
\text { Ugboula (UGB) }\end{array}$ & $\begin{array}{l}\text { Etikan I (ETK 1) } \\
\text { Etikan } \Perp \text { (ETK 2) } \\
\text { Igboikoda (GBN) } \\
\text { Hara (ILR) } \\
\text { Tpare (JPR) } \\
\text { Mahiu (MHN) } \\
\text { Okoga (OKG) } \\
\text { Palm Village (PLV) } \\
\text { Salem Querters (SLQ) }\end{array}$ & $\begin{array}{l}\text { Ojuala (JLP) } \\
\text { Ugbotu-Zion (GTZ) } \\
\text { Uglotu-Bolorunduro (GTB) } \\
\text { Igbobini (IGK) } \\
\text { Tgbekebo-Okoto (GKO) } \\
\text { Igbelkebo-Pekagha (GKP) } \\
\text { Sabomi I (SBM) } \\
\text { Sabomi II (SBM 2) } \\
\text { Kiribo I (KRB 1) } \\
\text { Kiribo II (KRB 2) }\end{array}$ \\
\hline
\end{tabular}

Table 1: Ilaje and Ese-Odo Coastal Communities Divided Into Districts

\subsection{Sample Collection and Treatment}

Thirty borehole points of various geographic locations was used for the study using a Global Positioning System (GPS) device. Sampling was carried out on the thirty borehole points within the selected communities of the coastal area which are grouped into districts I, II and III. Samples were taken thrice in each season of dry and rainy of 2018 and 2019 respectively. Again, samples were taken from three different urban water supply schemes (water works) which include Owena-Ondo, Owena-Ilesa and Alagbaka-Akure as district 1 to serve as control. A total of two hundred and sixty-four samples were taken for rainy and dry seasons respectively in all the communities of the study area.

\subsection{Sample Digestion}

Metal's pre-treatment was done according to standard method stated by APHA, (2005). A $200 \mathrm{ml}$ portion of thoroughly mixed water sample was measured into a glass beaker and $3 \mathrm{ml}$ conc. $\mathrm{HNO}_{3}$ added. The beaker was then placed 
on a hot plate and evaporated to almost dryness. The sample was filtered through a Whatman (No.4) filter paper into 20 $\mathrm{ml}$ volumetric flask and diluted to mark with distilled water.

\subsection{Quantitative Analysis of Metals}

Metals were analysed for $\mathrm{Cu}, \mathrm{Pb}, \mathrm{Cd}, \mathrm{Cu}, \mathrm{Zn}, \mathrm{Cr}, \mathrm{Ni}, \mathrm{Fe}, \mathrm{Mn}, \mathrm{Co}$ and Vat their respective wavelength (324.8, 281.5, $227,323,213.9,358,231,248.3,278,240.7$ and $318.4 \mathrm{~nm}$ ) after digestion using clean filtrate of the samples by means of Atomic Absorption Spectrophotometry according to standard methods. Metal concentrations were measured using a flame Atomic Absorption Spectrophotometer (Buck Scientific Model) 200A. A blank (distilled water) was carried out through the same procedure and results were expressed in $\mathrm{mg} / \mathrm{L}$. The limit of detection for $\mathrm{Cd}$ was $0.001 \mathrm{and} 0.01 \mathrm{ppm}$ forCr, $\mathrm{Pb}, \mathrm{Fe}$, $\mathrm{Cu}, \mathrm{Ni}, \mathrm{Mn}$, and $\mathrm{Zn}$ samples were analyzed in triplicate.

\subsection{Quality Assurance Procedure}

Special precautions for quality assurance during the study were considered a priority. All reagents were of analytical grade and water samples for metal analysis were preserved with $3 \mathrm{ml}$ concentrated $\mathrm{HNO}_{3}$ per litre in the field. Sample used for determination of heavy metals was collected in plastic bottles. The plastics and glassware's were thoroughly washed with detergent, rinsed with tap water and later soak for 48 hours in $50 \% \mathrm{HNO}_{3}$, rinsed thoroughly with distilled-deionized water and glass containers baked in the oven at $200^{\circ} \mathrm{C}$.

\section{Results and Discussion}

\begin{tabular}{|c|c|c|c|c|c|}
\hline $\begin{array}{l}\text { Sampling Points } \\
\text { Districts }\end{array}$ & $\begin{array}{l}\text { Zinc } \\
(\mathbf{m g} / \mathbf{L})\end{array}$ & $\begin{array}{c}\text { Chromium } \\
(\mathbf{m g} / \mathbf{L})\end{array}$ & $\begin{array}{l}\text { Iron } \\
(\mathbf{m g} / \mathbf{L})\end{array}$ & $\begin{array}{c}\text { Cadmium } \\
(\mathbf{m g} / \mathbf{L})\end{array}$ & $\begin{array}{l}\text { Nickel } \\
(\mathbf{m g} / \mathbf{L})\end{array}$ \\
\hline I & $0.14 \pm 0.01^{\circ}$ & $0.003 \pm 0.00^{\circ}$ & $0.44 \pm 0.04^{\circ}$ & abc. & aec \\
\hline Rainy & $0.01 \pm 0.00^{\circ}$ & $0.01 \pm 0.00^{\circ}$ & $0.82 \pm 0.10^{\circ}$ & $0.01 \pm 0.00^{\circ}$ & $0.004 \pm 0.10^{\circ}$ \\
\hline II & $0.03 \pm 0.02^{\circ}$ & $0.01 \pm 0.00$ & $0.62 \pm 0.21^{\vee}$ & $0.003 \pm 0.00^{\circ}$ & $0.001 \pm 0.10^{\circ}$ \\
\hline IV & $0.01 \pm 0.06^{\circ}$ & $0.01 \pm 0.00^{\circ}$ & $0.34 \pm 0.07^{\circ}$ & $0.002 \pm 0.00^{\circ}$ & $0.001 \pm 0.10^{\circ}$ \\
\hline Mean \pm S.E & $0.03 \pm 0.01$ & $0.01 \pm 0.00$ & $0.58 \pm 0.07$ & $0.003 \pm 0.00$ & $0.003 \pm 0.00$ \\
\hline
\end{tabular}

Table 2: Seasonal Mean Concentration of Heavy Metals in Borehole Waters in the Coastal Areas of Ondo State

\begin{tabular}{|c|c|c|c|c|c|}
\hline $\begin{array}{l}\text { Sampling Points } \\
\text { Districts }\end{array}$ & $\begin{array}{l}\text { Manganese } \\
(\mathrm{mg} / \mathrm{L})\end{array}$ & $\begin{array}{l}\text { Copper } \\
(\mathrm{mg} / \mathrm{L})\end{array}$ & $\begin{array}{l}\text { Lead } \\
(\mathrm{mg} / \mathrm{L})\end{array}$ & $\begin{array}{l}\text { Cobalt } \\
(\mathrm{mg} / \mathrm{L})\end{array}$ & $\begin{array}{c}\text { Vanadium } \\
(\mathrm{mg} / \mathrm{L})\end{array}$ \\
\hline I & $0.10 \pm 0.05^{\prime}$ & $0.07 \pm 0.02^{\circ}$ & $0.01 \pm 0.00^{\circ}$ & $0.01 \pm 0.00^{\circ}$ & $0.003 \pm 0.00$ \\
\hline Rainy & $0.02 \pm 0.01^{\circ}$ & $0.01 \pm 0.00^{\circ}$ & $0.01 \pm 0.00^{4}$ & $0.002 \pm 0.00^{\circ}$ & \\
\hline III & $0.01 \pm 0.01^{\circ}$ & $0.01 \pm 0.00^{\circ}$ & $0.21 \pm 0.00^{\circ}$ & $0.01 \pm 0.00^{\circ}$ & \\
\hline IV & $0.02 \pm 0.00^{\mathrm{k}}$ & $0.001 \pm 0.00^{4}$ & $0.003 \pm 0.00^{\circ}$ & $0.003 \pm 0.00^{\circ}$ anc & \\
\hline$\star * \star * *$ Mean \pm S.E & $0.02 \pm 0.01$ & $0.02 \pm 0.00$ & $0.01 \pm 0.00$ & $0.004 \pm 0.00$ & $0.003 \pm 0.00$ \\
\hline
\end{tabular}

Table 3: Seasonal Mean Concentration of Heavy Metals in Borehole Waters in the Coastal Areas of Ondo State

\begin{tabular}{|c|c|c|c|c|c|}
\hline $\begin{array}{l}\text { Sampling Points } \\
\text { Districts }\end{array}$ & $\begin{array}{l}\text { Zinc } \\
(\mathrm{mg} / \mathrm{L})\end{array}$ & $\begin{array}{l}\text { Chromium } \\
(\mathrm{mg} / \mathrm{L})\end{array}$ & $\begin{array}{r}\text { Iron } \\
(\mathrm{mg} / \mathrm{L})\end{array}$ & $\begin{array}{c}\text { Cadmium } \\
(\mathrm{mg} / \mathrm{L})\end{array}$ & $\begin{array}{l}\text { Nickel } \\
(\mathrm{mg} / \mathrm{L})\end{array}$ \\
\hline I & $0.12 \pm 0.02^{*}$ & $0.01 \pm 0.01^{\circ}$ & $0.27 \pm 0.09^{\prime}$ & $0.01 \pm 0.01^{\prime}$ & $0.003 \pm 0.01^{\circ}$ \\
\hline Dry & $0.01 \pm 0.01^{b}$ & $0.02 \pm 0.01^{2}$ & $0.11 \pm 0.15^{\text {sb } \mathrm{abl}}$ & \multicolumn{2}{|c|}{$0.01 \pm 0.00^{2}$} \\
\hline III & $0.03 \pm 0.01^{\circ}$ & $0.02 \pm 0.03^{\circ}$ & $0.15 \pm 0.19 *$ & \multicolumn{2}{|c|}{$0.01 \pm 0.00^{n}$} \\
\hline IV & $0.02 \pm 0.02^{\circ}$ & $0.01 \pm 0.01^{\prime}$ & $0.05 \pm 0.06^{\circ}$ & exc. & $0.001 \pm 0.00^{\circ}$ \\
\hline Mean \pm S.E & $0.03 \pm 0.04$ & $0.01 \pm 0.01$ & $0.12 \pm 0.15$ & $0.01 \pm 0.01$ & $0.00 \pm 0.01$ \\
\hline
\end{tabular}

Table 4: Seasonal Mean Concentration of Heavy Metals in Borehole Waters in the Coastal Areas of Ondo State 


\begin{tabular}{|c|c|c|c|c|c|}
\hline $\begin{array}{l}\text { Sampling Points } \\
\text { Districts }\end{array}$ & $\begin{array}{l}\text { s Manganese } \\
(\mathrm{mg} / \mathrm{L})\end{array}$ & $\begin{array}{l}\text { Copper } \\
\text { (mg/L) }\end{array}$ & $\begin{array}{r}\begin{array}{c}\text { Lead } \\
(\mathrm{mg} / \mathrm{L})\end{array} \\
\text { (1) }\end{array}$ & $\begin{array}{l}\text { Cobalt } \\
(\mathrm{mg} / \mathrm{L})\end{array}$ & $\begin{array}{c}\text { Vanadium } \\
(\mathrm{mg} / \mathbf{L})\end{array}$ \\
\hline I & $0.09 \pm 0.03^{\circ}$ & $0.17 \pm 0.04^{2}$ & $0.15 \pm 0.04^{\circ}$ & $0.03 \pm 0.00^{2}$ & $0.003 \pm 0.00^{\circ}$ \\
\hline Dry & $0.01 \pm 0.01^{\circ}$ & $0.01 \pm 0.01^{b}$ & $0.001 \pm 0.00^{b}$ & $0.001 \pm 0.00^{b}$ & BDL \\
\hline III & $0.03 \pm 0.02^{\circ}$ & $0.01 \pm 0.01^{\circ}$ & BDL & BDL & BDL \\
\hline IV & $0.01 \pm 0.01^{\circ}$ & $0.001 \pm 0.01^{\circ}$ & BDL & BDL & BDL \\
\hline Mean \pm S.E & $0.03 \pm 0.01$ & $0.01 \pm 0.04$ & $0.003 \pm 0.01$ & $0.002 \pm 0.01$ & $0.003 \pm 0.00$ \\
\hline
\end{tabular}

\subsection{Discussion}

Water being an important solvent needed for the sustenance of life is threatened by heavy metal contaminants, thus this has become a main concern to the scientist because of their deleterious effects on human health, plants and animals (Folasade, 2010; Christopher 2011). For the metals in general of which $\mathrm{Zn}, \mathrm{Cr}, \mathrm{Fe}, \mathrm{Cd}, \mathrm{Ni}, \mathrm{Cu}, \mathrm{Pb}, \mathrm{Co}$ and $\mathrm{V}$ were determined, quite a number of these metals had levels that were below detection limits.

\subsubsection{Zinc}

The concentrations of $\mathrm{Zn}$ in borehole water samples were $0.03 \pm 0.01 \mathrm{mg} / \mathrm{L}$ and $0.03 \pm 0.04 \mathrm{mg} / \mathrm{L}$ for rainy and dry seasons respectively. The level of Zinc in all districts during the study in both rainy and dry seasons was below $0.5 \mathrm{mg} / \mathrm{L}$, the WHO recommended level. There was no significant $(\mathrm{p}<0.05)$ difference between the concentrations of Zn during the rainy and dry seasons in the districts. This study disagreed with similar study reported by Papafilippakiet.al., (2008) where zinc levels were significantly higher in warm period than cold period due to change in river flow and water temperature.Oliaset.al., (2004) observed that a concentration effect of dissolved zinc could also occur in water during dry season due to water evaporation. In a similar study corroborating this study, seasonal variation of zinc was found to be higher in summer than winter period (Daifullahet.al., 2003). High zinc presence protects people from cadmium poisoning (Varrialeet.al., 2007). Cadmium toxicity is greatly increased with zinc deficiency (Goyer, 1997). The human body only absorbs $20-40 \%$ of zinc present in food consequently; many people drink mineral water that is rich in $\mathrm{Zn}$ (Appolonia and Juliet, 2013). Although, Zn is an essential requirement for good health, excess zinc can be harmful (Wang et.al., 2006; Maret and Sandstead, 2006).

\subsubsection{Chromium}

Chromium had concentrations of $0.01 \pm 0.00 \mathrm{mg} / \mathrm{L}$ and $0.014 \pm 0.01 \mathrm{mg} / \mathrm{L}$. These concentrations were found below the internationally recommended levels of $0.05 \mathrm{mg} / \mathrm{l}$ in all the districts during rainy and dry seasons. The generally low levels of chromium in the sampled boreholes was in contrast to the study reported by Ali (2004) on industrial effluent in Pakistan where higher levels of chromium in water than the recommended value was observed. In this study, no accumulation of chromium was noticeable in rainy and dry seasons $(0.01 \mathrm{mg} / \mathrm{L}$ and $0.02 \mathrm{mg} / \mathrm{L})$. This could be explained on the basis of low solubility of heavy metals as a result of less dilution of water and warm temperature. An average concentration of $0.01 \mathrm{mg} / \mathrm{L}$ chromium in rainy and $0.05 \mathrm{mg} / \mathrm{L}$ in dry seasons in a study on heavy metals in groundwater of Mandeep reported by Han et.al., (2000) corroborated the result of this study. Chromium (III) compounds are less damaging to health due to their limited absorption (4\%) by the body, while chromium (IV) compounds are actually poisonous. However, when in contact with the skin, it could trigger dermatitis, allergies and irritations, thus considered carcinogenic to humans (Aliet.al., 2005). The differential geochemical and biologic behaviour of Cr (VI) and Cr (III) has led

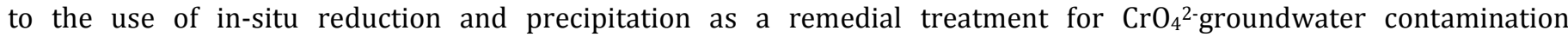
(Fruchteret.al., 2000).

\subsubsection{Iron}

Iron is a potent dietary antagonist of copper metabolism in ruminants hence may be injurious to health when found above the WHO (1993) minimum recommended standard of 1.0mg/L. However, results in district II \& III were below this value in rainy and dry seasons respectively. In rainy season, slightly elevated concentrations of iron are more visible in the borehole samples in district II \& III $(0.82 \pm 0.10 \mathrm{mg} / \mathrm{L}$ and $0.62 \pm 0.21 \mathrm{mg} / \mathrm{L})$ than dry season $(0.11 \pm 0.15 \mathrm{mg} / \mathrm{L}$ and $0.15 \pm 0.19 \mathrm{mg} / \mathrm{L}$ in the same districts. It was observed that there was a significant $(\mathrm{p}<0.05)$ difference in the concentrations of $\mathrm{Fe}$ in the borehole waters of all the coastal districts of Ondo State, in both seasons. Iron (Fe) was higher in districts I, II and III than in districts IV $(0.27 \pm 0.09 \mathrm{mg} / \mathrm{L}, 0.11 \pm 0.15 \mathrm{mg} / \mathrm{L}, 0.15 \pm 0.19 \mathrm{mg} / \mathrm{Land} 0.05 \pm 0.06 \mathrm{mg} / \mathrm{L})$ respectively in dry season. These values were low compared with $122.39 \mathrm{mg} / \mathrm{L}$ and $180.84 \mathrm{mg} / \mathrm{L}$ reported by Alukoet.al., (2003).

Fe is an important element required for the synthesis of haemoglobin during haemopoiesis in the bone marrow (Nemeth, 2008). Alagbe (2002) reported some high iron groundwaters in basement rocks of North central Nigeria, although all were found to be below the WHO guideline value. Malomaet.al., (1990) found concentrations of iron up to 5 $\mathrm{mg} / \mathrm{l}$ in artesian well from Southwest, Nigeria. Concentrations of total iron up to $2 \mathrm{mg} / \mathrm{l}$ were reported in groundwaters from sedimentary aquifers of AkwaIbom state, South-south Nigeria (Akujiezeet.al., 2003). Okagbue (1988) found 
concentrations of total iron up to $1.10 \mathrm{mg} / \mathrm{L}$ in the Southeast sedimentary aquifers. Amadiet.al., (1989) found total iron concentrations up to $6.2 \mathrm{mg} / \mathrm{l}$ in groundwaters from the Niger delta. The maxima observed for iron in these aquifers were well over the WHO guideline values for drinking water, although consideration for iron is on aesthetic rather than health grounds and iron is not considered detrimental to health.

\subsubsection{Manganese}

Manganese compounds exist naturally in the soils and small particles in water, it is also toxic when high concentrations are present in the human body leading to neurological, organ and cardiac problems (Cooper, 1984). Although, none of the samples contained $\mathrm{Mn}$ in excess of the recommended standard in this study. The Concentrations of Mn were $0.02 \pm 0.01 \mathrm{mg} / \mathrm{L}$ and $0.03 \pm 0.01 \mathrm{mg} / \mathrm{L}$ for rainy and dry seasons respectively. The results obtained for manganese in this study, tallied to a reasonable extent with the reported work of Ugochukwu and Leton (2004) which showed lower concentration during the rainy season. High level of manganese in form of permanganate is harmful and could kill fish at concentration between $2.0-4.0 \mathrm{mg} / \mathrm{L}$. It is pertinent to point outthat manganese contamination would result in neurological disorders in exposed persons (Duruibeet.al., 2007). It has been reported that headaches, involuntary movements, sleep, speech and gait disturbances as well as exaggerated reflexes significantly increase with increasing duration of exposure to Mn (Badawy and Shakour, 1985; Itah and Akpan, 2005).

\subsubsection{Lead}

Increase in lead concentration could be due to $\mathrm{Pb}$ deposition on the soil surface via wet deposition of air borne $\mathrm{Pb}$ particulates. Airborne lead could be primarily traced to vehicular emissions and application of Pb containing pesticides (Sridhar, 2000). The mean concentrations of lead were $0.01 \pm 0.00 \mathrm{mg} / \mathrm{L}$ and $0.003 \pm 0.01 \mathrm{mg} / \mathrm{L}$ in rainy and dry seasons. However, results from this study showed that most of the borehole samples recorded very low lead concentrations and were not detected in district III \& IV in dry season. The results also revealed that few districts had greater mean values of lead than the $0.005 \mathrm{mg} / \mathrm{L}$ tolerable limit by WHO. These districts include; I and II in rainy season and I in dry season.

On the other hand, there was no significant difference $(p>0.05)$ in lead $(0.15 \pm 0.04 \mathrm{mg} / \mathrm{L})$ concentration in district I compared with lead $(0.08 \mathrm{mg} / \mathrm{L} \mathrm{Pb})$ concentration earlier reported for the same location by Ajayiet.al., (2009). The elevated $\mathrm{Pb}$ concentration in district III in rainy season $(0.21 \mathrm{mg} / \mathrm{L})$ could be as a result of oil spills or oil exploration around the study area (Babatunde, 2010; Eicken and Mahoney, 2014).However, Osuji and Onojake (2006) reported a ratio $>15$ in the sediment of Ebocha 8-oil spill polluted site in Niger Delta, Nigeria. Low levels of Pb generally recorded in both seasons were consistent with previous results in Niger Delta (Adeleyeet.al., 2011; Chindahet.al., 2009).

\section{Seasonal Concentrations of Heavy Metals in Borehole Waters in the Coastal Areas of Ondo State}

The concentrations of heavy metals of the borehole waters in the coastal areas on the basis of districts and for both dry and rainy seasons are shown in Table 2, $2 \mathrm{~b}, 3 \mathrm{a}$ and $3 \mathrm{~b}$ respectively. The mean values of the thirty three (33) communities sampled for heavy metals were: Zinc $(0.03 \pm 0.01 \mathrm{mg} / \mathrm{L})$, Chromium $(0.01 \pm 0.00 \mathrm{mg} / \mathrm{L}), \mathrm{Iron}(0.58 \pm 0.07 \mathrm{mg} / \mathrm{L})$, Cadmium $(0.00 \pm 0.00 \mathrm{mg} / \mathrm{L})$, Nickel $(0.00 \pm 0.00 \mathrm{mg} / \mathrm{L})$, Manganese $(0.02 \pm 0.01 \mathrm{mg} / \mathrm{L})$, Copper $(0.02 \pm 0.00 \mathrm{mg} / \mathrm{L}), \mathrm{Lead}$ $(0.01 \pm 0.00 \mathrm{mg} / \mathrm{L})$, Cobalt $(0.00 \pm 0.00 \mathrm{mg} / \mathrm{L})$ and Vanadium $(0.00 \pm 0.00 \mathrm{mg} / \mathrm{L})$. For dry season, the concentrations were found higher than values obtained in rainy season, with the exception of concentration for Iron $(0.58 \pm 0.07 \mathrm{mg} / \mathrm{L})$ that was higher in rainy season.

Results on district bases showed that District I had highest mean values for Zinc $(0.14 \pm 0.01 \mathrm{mg} / \mathrm{L}$ and $0.12 \pm 0.02 \mathrm{mg} / \mathrm{L})$, Manganese $(0.10 \pm 0.05 \mathrm{mg} / \mathrm{L}$ and $0.10 \pm 0.03 \mathrm{mg} / \mathrm{L})$, Copper $(0.10 \pm 0.02 \mathrm{mg} / \mathrm{L}$ and $0.2 \pm 0.04 \mathrm{mg} / \mathrm{L}), \mathrm{Lead}$ $(0.01 \pm 0.00 \mathrm{mg} / \mathrm{L}$ and $0.15 \pm 0.04 \mathrm{mg} / \mathrm{L})$ and Cobalt $(0.01 \pm 0.00 \mathrm{mg} / \mathrm{L}$ and $0.03 \pm 0.00 \mathrm{mg} / \mathrm{L})$ for rainy and dry seasons respectively. District II had highest mean concentration for Iron $(0.82 \pm 0.10 \mathrm{mg} / \mathrm{L})$ in rainy season while Vanadium was below detection level in District II, III and IV in both seasons respectively. On a comparative basis of concentrations for the 33 communities to that of the individual values for the districts, it was observed that the concentrations for the districts in both seasons were consistently higher than that for all the communities put together.

\section{Conclusion}

The results of heavy metals of the water samples were within the WHO permissible levels with the exception of Lead. However, there is need to put in place facilities for potable water in order to prevent accumulation of lead which can pose health risk to humans, animals and the ecosystem.

\section{References}

i. Adeleke, M. L., Omogbemi, T. E. and Ogunjobi, V. O. 2015. Value Chain Strategies in Fish Production for food Security in Nigeria: The Case of Selected Key Actors in Fish Production in Ondo State Coastal Areas. International Journal of Innovative Research and Development// ISSN 2278-0211, 4(13).

ii. Adeleye, A. O., Shelle, R. O. D. and Akinnigbagbe, A. E. 2011. Pollutant dynamics and distribution in sediments north of Lagos Lagoon ecosystem. Nature and Science, 9(5): 13-16.

iii. Ajayi, A. O., Balogun, S. A. and Adegbehingbe, K. T. 2009. Microbes and mineral elements in oil producing area of Ondo State, Nigeria. American-Eurasian Journal of Scientific Research, 4(3), 204-212.

iv. Akujieze, C.N., Coker, S.J. and Oteze, G.E. 2003. “Groundwater in Nigeria- a millennium experience-Distribution, practice, problems and solutions".i Hydrogeology Journal.1: 259-274.

v. Alagbe, S. 2002. Groundwater resources of river Kan Gimi Basin, north-central, Nigeria. Environmental Geology, 42(4), 404-413. 
vi. Ali, M.U. 2004. Toxicological effects of industrial effluents dumped in River Kabul on MahaseerLorputitiora at AmanGarh industrial area, Nowshera, Pehsawar, Pakistan. Pakistan Research Repository, published by Higher Education Commission, Pakistan. 340p

vii. Ali, N., Oniye, S.T., Balarabe, M.L., Auta, J. 2005. Concentration of Fe, Cu, Cr, Zn and Pb in Makere-Drain. Kaduna, Nigeria. Chemclass Journal, 2: 69-73

viii. Aluko, O. O., Sridhar, M. K. and Oluwande, P. A. 2003. Characterization of leachates from a municipal solid waste landfill site in Ibadan, Nigeria. Journal of Environmental Health Research, 2(1): 32-37.

ix. Amadi, P.A., Ofoegbu, C.O. and Morrison, T. 1989. Hydrogeochemical assessment of groundwater quality in parts of the Niger delta, Nigeria. Environmental Geology \& Water Sciences. 14: 195-202.

x. APHA, 2005. Standard Methods for the Examination of Water and Wastewater, 21 stEdition.

xi. Appolonia, K. I. and Mgbodom-Okah C.J. 2013. Water analysis for heavy metals content in selected boreholes in Port Harcourt metropolis (a case study during 2010-2011). Journal of Environmental Science and Engineering. A, $2(7 \mathrm{~A}), 418$.

xii. Atubi, A. O. (2011). Effects of warri refinery effluents on water quality from the Iffie River, Delta State, Nigeria. American Review of Political Economy, 9(1), 45.

xiii. Babatunde, A. 2010.The impact of oil exploitation on the socioeconomic life of the Ilaje-ugbo people of Ondo state, Nigeria. Journal of Sustainable Development in Africa, 12(5): 61-84.

xiv. Badawy, A. B. N. and Shakour, A. A. 1985. Chronic manganese intoxication (neurological manifestations). In Trace elements in man and animals: TEMA 5: proceedings of the fifth International Symposium on Trace Elements in Man and Animals/editors CF Mills, I.

xv. Chindah, A. C., Braide, S. A., Amakiri, J. and Chikwendu, S. O. N. 2009. Heavy metal concentrations in sediment and periwinkle-Tympanotonusfuscastus in the different ecological zones of Bonny River system, Niger Delta, Nigeria. The Open Environmental Pollution and Toxicology Journal, 2(1): 14-19.

xvi. Christopher, A. 0. 2011. Environmental Aesthetics and Sustainable Tourism Development in Nigeria: A Stakeholder Participatory Approach. Sustainable Development and Environmental Protection, 1(1): 30-40.

xvii. Cooper, W.C. 1984. The health implications of increased manganese in the environment resulting from the combustion of fuel additives: a review of the literature. Journal of Toxicology and Environmental Health, Part A Current Issues, 14(1): 23-46.

a. Corvalan, C., Hales, S., \& McMichael, A. J. (2005). Ecosystems and human well-being: health synthesis. World health organization.

xviii. Daifullah, A. A. M., Elewa, A. A., Shehata, M. B. and Abdo, M. H. 2003. Evaluation of some heavy metals in water, sediment and fish samples from River Nile (Kafr El-Zyat City), Egypt: a treatment approach. African Journal of Environmental Assessment and Management/Revue africaine de gestionetd'evaluationenvironnementales, 6: 1631.

xix. Duruibe, J. O., Ogwuegbu, M. O. C. and Egwurugwu, J. N. 2007. Heavy metal pollution and human biotoxic effects. International Journal of Physical Sciences, 2(5): 112-118.

xx. Eicken, H. and Mahoney, A. R. 2014. Sea Ice: Hazards, Risks, and Implications for Disasters. Coastal and Marine Hazards, Risks, and Disasters, p.381.

xxi. Efe, S. I., Ogban, F. E., Horsfall, M. J. and Akporhonor, E. E. 2005. Seasonal variations of physico-chemical characteristics in water resources quality in western Niger Delta region, Nigeria.

xxii. Folasade, O. J. 2010. The Impact of Human Activities on Coastal Zone for Sustainable Livelihood. Sustainable Development \& Environmental Protection, 67-78.

xxiii. Fruchter, J. S., Cole, C. R., Williams, M. D., Vermeul, V. R., Amonette, J. E., Szecsody, J. E. and Humphrey, M. D. 2000. Creation of a subsurface permeable treatment zone for aqueous chromate contamination using in situ redox manipulation. Groundwater Monitoring \& Remediation, 20(2): 66-77.

xxiv. Goyer, R. A. 1997. Toxic and essential metal interactions. Annual Review of Nutrition, 17(1): 37-50.

xxv. Han, I., Schlautman, M. A. and Batchelor, B. 2000. Removal of hexavalent chromium from groundwater by granular activated carbon. Water Environment Research, 72(1): 29-39.

xxvi. Itah, A. Y. and Akpan, C. E. 2005. Potability of drinking water in an oil impacted community in southern Nigeria.

xxvii. Maloma, S., Okufarasin, V.A., Olorunnio, M.A. and Omode, A.A. 1990. Groundwater chemistry of weathered zone aquifers of an area underlain by basement complex rocks. Journal of African Earth Sciences, 11, p.357-371.

xxviii. Maret, W. and Sandstead, H. H. 2006. Zinc requirements and the risks and benefits of zinc supplementation. Journal of Trace Elements in Medicine and Biology, 20(1):3-18.

xxix. National Population Commission 2006.Census Population Figure.

xxx. Nduka, J. K., and Orisakwe, O. E. (2010). Water Quality Issues in the Niger Delta of Nigeria: Polyaromatic and Straight Chain Hydrocarbons in Some Selected Surface Waters. Water Quality, Exposure and Health, 2(2),65-74.

xxxi. Nduka, J. K., and Orisakwe, O. E. (2011). Water-quality issues in the Niger Delta of Nigeria: a look at heavy metal levels and some physicochemical properties. Environmental Science and Pollution Research, 18(2), 237-246.

xxxii. Nemeth, E. 2008. Iron regulation and erythropoiesis. Current opinion in hematology, 15(3), 169-175.

xxxiii. Offiong, O. J., and Cocodia, J. 2011. Charting Pathways to Development in the Riverine Areas of Nigeria's Niger Delta Region. International Journal of politics and good governance, 2, 22.

xxxiv. Okagbue, C.O. 1988. Hydrology and chemical characteristics of surface and groundwater resources of the Okigwi area and environs, Imo State, Nigeria. In: Groundwater and Mineral Resources of Nigeria, pp 3-16. 
xxxv. Olias, M., Nietob, J.M., Sarmientob, A.M., Cerona, J.C. and Canovasa, C.R. 2004. Seasonal quality variations in a river affected by acid mine drainage: the Odiel River, South West Spain. Science of the Total Environment, 333: 267-281.

xxxvi. Osuji, L. C. and Onojake, C. M. 2006. Field reconnaissance and estimation of petroleum hydrocarbon and heavy metal contents of soils affected by the Ebocha-8 oil spillage in Niger Delta, Nigeria. Journal of Environmental Management, 79(2): 133-139.

xxxvii. Papafilippaki, A.K., Kotti, M.E. and Starronlakis, G.0. 2008. Seasonal variationsin dissolved heavy metals in the Keritis River, Chania. Greece. Global NEST Journal 10(3): 320-325.

xxxviii. SAS. 1999.www.ats.ucla.edu/stat/sas/library/sas anova_mf.htm

xxxix. Sridhar, M.K.C. 2000. Ground water in Nigerian urban centers: problems and options. SchriftenrVerWasserBoden Luftyg.105: 393-397

xl. Ugochukwu, C. N. C. and Leton, T. G. 2004. Effluent monitoring of an oil servicing company and its impact on the environment. African Journal of Environmental Assessment and Management, 8: 27-30.

xli. Varriale, A., Staiano, M., Rossi, M. and D'Auria, S. 2007. High-affinity binding of cadmium ions by mouse metallothionein prompting the design of a reversed-displacement protein-based fluorescence biosensor for cadmium detection. Analytical Chemistry, 79(15): 5760-5762.

xlii. Wang, B., Feng, W. Y., Wang, T. C., Jia, G., Wang, M., Shi, J. W. and Chai, Z. F. 2006. Acute toxicity of nano-and micro-scale zinc powder in healthy adult mice. Toxicology Letters, 161(2):115-123.

i. WHO. 1993. Guidelines for drinking water quality; vol.1. Recommendations $2^{\text {nd }}$ ed. Geneva. 8(29): 173-184. 